Studia i Materiały, 2/2016 (21), cz. 1: 143-156

\title{
Płace i emerytury w przyszłości. Na ile stać gospodarkę
}

\begin{abstract}
Andrzej Sopoćko*
Coraz dtuższe życie wydaje się przysparzać gospodarce problemów, a przede wszystkim - alarmistycznych opinii dotyczacych obciażeń pracujacych świadczeniami emerytalno-rentowymi. Rzeczywiście relacja między znajdującymi się $w$ tzw. wieku zdolności do pracy a starszymi pogarsza się. W ujęciu statycznym wyglada to bardzo niekorzystnie, inne jednak wrażenie odnosi się, gdy podejdzie się do tego dynamicznie, czyli uwzględniając wzrost wydajności pracy. $Z$ przedstawionych $w$ artykule wyliczeń wynika, że utrzymanie jej dtugookresowego wzrostu, nie tylko $w$ Polsce, lecz także w innych krajach europejskich, pozwala zarówno na wzrost plac realnych, jak i utrzymanie obecnego wskaźnika zastapienia (relacja: emeryturaptaca). Więcej optymizmu w tej sprawie można bytoby mieć przy utrzymaniu obecnego wieku emerytalnego. Przywrócenie starego (sprzed 2013) może, ale nie musi, spowodować pewne problemy, w postaci zablokowania realnej wysokości ptacy netto (przez rosnace sktadki lub zastępujacy je wzrost podatków). Wówczas prawdopodobnie obecnego wskaźnika zastapienia nie datoby się utrzymać. W niniejszym artykule autor przedstawia opis analizy liczbowej majacej za zadanie odpowiedzieć na pytanie: czy wobec realistycznie przyjętego wzrostu wydajności pracy (powyżej $1 \%$ rocznie) jest możliwe utrzymanie obecnego wspótczynnika zastapienia i jednoczesnego wzrostu ptacy realnej?
\end{abstract}

Słowa kluczowe: dystrybucja dochodu, system emerytalny, wynagrodzenia.

Nadesłany: 04.04.2016 | Zaakceptowany do druku: 08.11.2016

\section{Wages and Pensions in the Future. How Much the Economy Can Afford}

Longer life seems to augment economic problems, and - above all - alarming opinions are being voiced about the burden of pension benefits that is imposed on the working population. Indeed, the relationship between those of the so-called working age and the elderly is getting worse. In statistical terms, this looks very unfavourable, yet a different impression may be gained when the issue is approached dynamically, that is with account being taken of the increase in labour productivity. The calculations presented in the article show that, by maintaining its long-term growth not only in Poland but also in other European countries, both real wages may increase and the current replacement rate (pension-wage relationship) can be sustained. More optimism about it could ensue if the current retirement age were maintained. The re-establishment of the previous (pre-2013) retirement age may, but need not, cause some problems such as freezing real net wages (due to growing social security contributions or alternative tax increases). Then, the current replacement rate probably could not be retained. In this article, the author describes the quantitative analysis intended to answer the question: with a realistically assumed labour productivity growth (over 1\% per year), is it possible to maintain the current replacement rate and a simultaneous increase in real wages?

\footnotetext{
Prof. dr hab. Andrzej Sopoćko - Katedra Systemów Finansowych Gospodarki, Wydział Zarządzania Uniwersytetu Warszawskiego.

Adres do korespondencji: Katedra Systemów Finansowych Gospodarki, Wydział Zarządzania Uniwersytetu Warszawskiego, ul. Szturmowa 1/3, 02-687; e-mail: sopocko@wz.uw.edu.pl.
} 
Keywords: income distribution, pension system, wages.

Submitted: 04.04.2016 | Accepted: 08.11.2016

JEL: G22, J26, J31

\section{Założenia i metoda badawcza}

Przy rosnącej długości życia najlepiej byłoby, aby wraz nią rósł przesuwał się w górę wiek przejścia na emeryturę. Nie dzieje się tak, przede wszystkim z przyczyn politycznych. Zmiana wieku emerytalnego podoba się tylko wtedy, gdy próbuje się go obniżyć, na czym, jak się okazuje, można pozyskać znaczny, dodatkowy elektorat. Nawet jednak bez takiej zmiany, trzeba się liczyć z konsekwencjami niekorzystnych procesów demograficznych. W kolejnych latach baza świadczeniobiorców bardzo szybko rośnie, natomiast płacących składki - kurczy się. Widać to na podstawie prognozy demograficznej.

Rosnący udział emerytów w społeczeństwie oraz coraz większa liczba lat życia na emeryturze oznaczają, że dla samego utrzymania istniejącego PKB na głowę mieszkańca pracownicy powinni systematycznie zwiększać swoją wydajność, odnosząc $\mathrm{z}$ tego nieproporcjonalnie mniejsze korzyści. Znacząca część produkcji dodanej musi być przeznaczona na wypłaty dla emerytów i rencistów. Nie są to co prawda liczby, które mogą wystraszyć, jednak w obecnych realiach spowolnienia gospodarczego na świecie są godne uwagi.

Dla poprawności obliczeń trzeba jednak uwzglednić dwa fakty:

1. Część zdolnych do pracy nie pracuje; relację pracujących do ludności w tzw. wieku aktywności zawodowej przedstawia współczynnik aktywności zawodo- wej. Relację tę można przedstawić także dla poszczególnych grup wieku.

2. Ludzie zaprzestają pracy nie wtedy, gdy rozpoczyna się wiek emerytalny, ale wtedy, gdy chcą lub muszą.

3. Po otrzymaniu emerytury nie wszyscy przestają pracować. Wiek, w którym przechodzi się na emeryturę, określa się jako okres „dezaktywacji zawodowej”.

4. Po otrzymaniu emerytury część populacji dalej pracuje. Pracujący w wieku powyżej 65 lat nie są wliczani do współczynnika zatrudnienia. Ponieważ otrzymują emerytury, są beneficjentami systemu emerytalnego. Nie są jednak w całości utrzymywani przez pracujących przed emeryturą.

W dalszej części pracy podjęta zostanie próba oszacowania, jak emerytury obciążają płace, czyli ile powinna wynosić składka emerytalna $\mathrm{w}$ dwu wariantach wieku emerytalnego, tj. przy obecnie obowiązującym wieku emerytalnym oraz przy tym, który zamierza się, zgodnie z politycznymi obietnicami, przywrócić. Analiza dotyczy wyłącznie emerytur z FUS; nie obejmuje rolników, służb mundurowych ani rent socjalnych i powypadkowych. Te ostatnie są elementem polityki społecznej państwa i nigdzie wydatki z nimi związane nie są pokrywane w całości przez wpływy składkowe czy pochodzące z kont emerytalnych. Określają je możliwości państwa i rozstrzygnięcia polityczne.

Przedstawiona tu analiza ma pomóc w odpowiedzi na pytanie: „Jeśli system

Tabela 1. Ludność w grupach wieku do 2050 r. Prognoza GUS (w tys.)

\begin{tabular}{|c|r|r|r|r|r|r|r|r|r|r|}
\hline & $\mathbf{2 0 1 3}$ & $\mathbf{2 0 1 4}$ & $\mathbf{2 0 1 5}$ & $\mathbf{2 0 2 0}$ & $\mathbf{2 0 2 5}$ & $\mathbf{2 0 3 0}$ & $\mathbf{2 0 3 5}$ & $\mathbf{2 0 4 0}$ & $\mathbf{2 0 4 5}$ & $\mathbf{2 0 5 0}$ \\
\hline Ogółem & 38496 & 38462 & 38419 & 38138 & 37741 & 37185 & 36477 & 35668 & 34817 & 33951 \\
\hline $0-14$ & 5771 & 5751 & 5728 & 5659 & 5227 & 4856 & 4536 & 4302 & 4198 & 4120 \\
\hline $15-64$ & 27052 & 26845 & 26620 & 25285 & 24325 & 23683 & 23024 & 21937 & 20418 & 18733 \\
\hline $65+$ & 5673 & 5865 & 6071 & 7194 & 8189 & 8646 & 8917 & 9429 & 10201 & 11097 \\
\hline $80+$ & 1483 & 1522 & 1560 & 1684 & 1680 & 2206 & 2869 & 3373 & 3473 & 3537 \\
\hline
\end{tabular}

Źródło: http://stat.gov.pl/obszary-tematyczne/ludnosc/prognoza-ludnosci/prognoza-ludnosci-na-lata2014-2050-opracowana-2014-r-, 1,5.html. 
Rysunek 1. Aktywność zawodowa w grupach wieku w 2013 roku

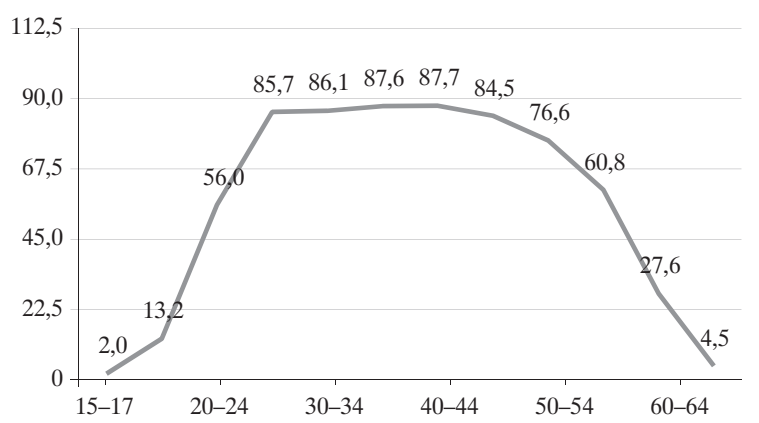

Źródło: http://www.zus.pl/files/Okres_aktywnosci_zawodowej_pracownikow_50_plus.pdf

emerytalny miałby się finansować sam, to jak powinny rosnąć składki, by przy pogarszającej się sytuacji demograficznej utrzymać ten sam co teraz wskaźnik zastąpienia?".

Kalkulacja tych obciążeń nie jest jednak prognozą wypłat i obciążeń wynikających z obecnych regulacji i algorytmów FUS. Te przecież na przestrzeni dziesięcioleci będą się zmieniać wielokrotnie. Chodzi wyłącznie o podstawową kwestię makroekonomiczną: czy gospodarka jest w stanie utrzymać ciągłość rozwoju, jeśli ma być zachowana obecna relacja płaca-emerytura.

Jest to niewątpliwie problem teoretyczny, ale ważny z punktu widzenia regulacji i konstrukcji każdego z rozważanych systemów emerytalnych. Celem wiodącym tworzenia każdego $\mathrm{z}$ nich nie może być sama postać algorytmu wypłaty, ale odpowiedź na pytanie, czy gdyby prowadził on do utrzymania obecnego wskaźnika zastąpienia, niezbecdne składki emerytalne nie spowodowałyby nadmiernego obciążenia płacy. A więc czy nie wyeliminowały one w praktyce materialnych przesłanek podnoszenia wydajności pracy?

\section{Wiek dezaktywacji zawodowej}

Wiek dezaktywacji zawodowej oznacza liczbę lat, po których, średnio rzecz biorąc, przechodzi się emeryturę/rentę. Nie dla wszystkich jest on równoznaczny z zaprzestaniem pracy; po osiagnnięciu tego wieku część osób będzie kontynuowała prace.

Praktycznie we wszystkich krajach EU wiek dezaktywacji zawodowej jest niższy od ustawowego wieku emerytalnego.

Jak widać z danych zamieszczonych na rysunku 2, tylko w czterech niewielkich krajach dezaktywacja zawodowa następuje później niż ustawowy wiek emerytalny. Nie jest to także parametr stały. Część osób po osiągnięciu wieku emerytalnego, a nawet i przed nim, faktycznie przestaje pracować. Zależy przynajmniej od kilku czynników, takich jak stan zdrowia, sytuacja rodzinna,

Rysunek 2. Ustawowy wiek emerytalny (linia pozioma) i wiek dezaktywacji zawodowej

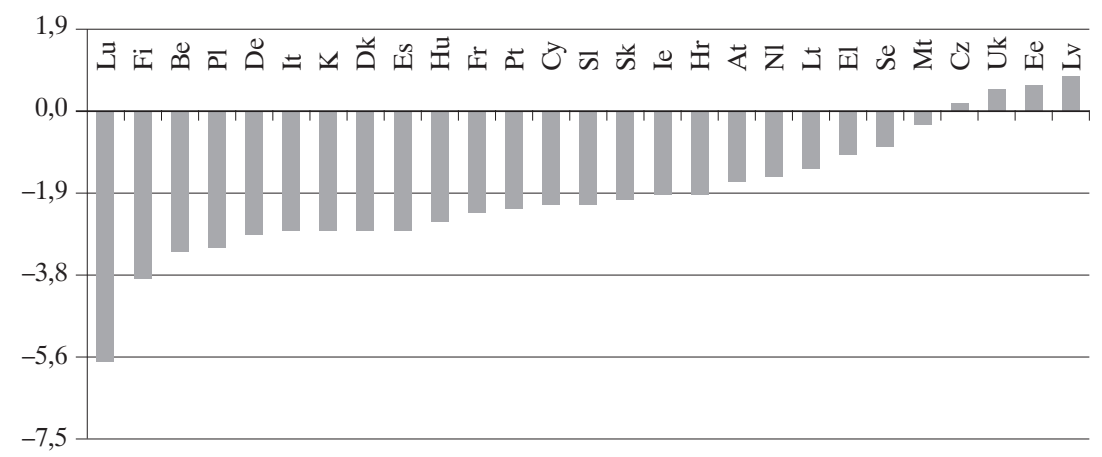

Źródło: von Nordheim (2014).

Wydział Zarządzania UW ～DOI 10.7172/1733-9758.2016.21.12 
Rysunek 3. Średni wiek dezaktywacji zawodowej w Polsce

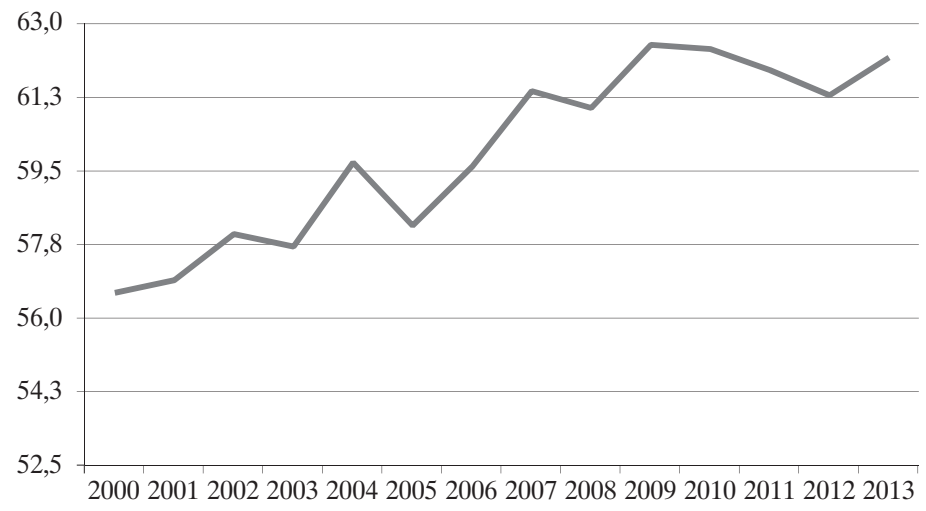

Źródło: opracowanie na podstawie danych z tabeli 3.

wysokość emerytury itp. ${ }^{1}$, obawa przed utratą pracy i przejściowego braku jakichkolwiek źródeł utrzymania ${ }^{2}$. Znaczna liczba osób pracuje jednak dalej, a sięgnięcie po emeryture jest zapewnieniem sobie dodatkowego dochodu.

Kolejnym elementem do oszacowania skali obciążeń emerytalnych jest wskaźnik zatrudnienia. Dla obliczenia jego wielkości w czasie przyszłych relacji dobrze byłoby mieć takie parametry jak sytuacja na rynku pracy, zdrowie ludności i jej dobrostan itp. Oszacowanie ich jest bardzo trudne, a wynik watpliwy. Trzeba poprzestać na tym, co jest $\mathrm{w}$ miarę pewne. Jednym $\mathrm{z}$ niewielu parametrów, które można uznać za dobra podstawe do obliczeń, wydaje się jedynie prognoza długości życia. Dane GUS przedstawiono w tabeli 2.

Tabela 2. Przeciętna prognozowana długość życia do roku 2050

\begin{tabular}{|c|c|c|}
\hline & Mężczý́ni & Kobiety \\
\hline 2013 & 73,1 & 81,1 \\
\hline 2015 & 73,5 & 81,5 \\
\hline 2020 & 74,9 & 82,5 \\
\hline 2025 & 76,3 & 83,6 \\
\hline 2030 & 78,0 & 84,8 \\
\hline 2035 & 79,1 & 85,6 \\
\hline 2040 & 80,3 & 86,5 \\
\hline 2045 & 81,6 & 87,4 \\
\hline 2050 & 83,3 & 88,4 \\
\hline
\end{tabular}

Dane zawarte w tabeli 2 dotycza przyszłości, którą w procesach demograficznych można określić z wysokim prawdopodobieństwem. Jaka jest jednak siła zależności między wiekiem przeżycia, wskaźnikiem zatrudnienia i dezaktywacji zawodowej-stwierdzić można tylko na podstawie istniejących danych. Zestawienie tych trzech wielkości, tj. współczynnika aktywności zawodowej, współczynnika dezaktywacji zawodowej przedstawiono w tabeli 3 i na rysunku 4.

Rysunek 4. Współczynnik zatrudnienia dezaktywacji oraz długość życia w latach 2000-2014

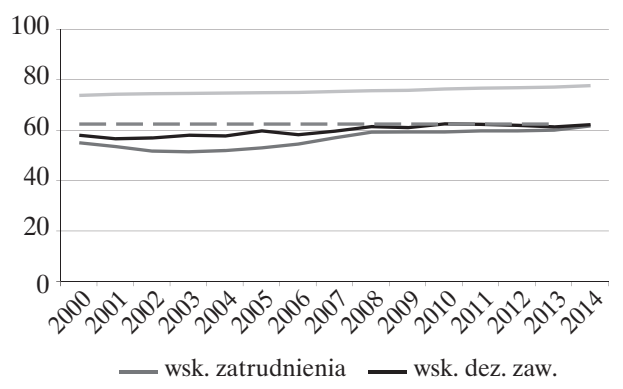

Źródło: opracowanie na podstawie danych z tabeli 3.

Przyglądając się rysunkowi 4 , trudno wychwycić zależności miedzy wykreślonymi danymi. Zbieżność liczbowa wskaźnika zatrudnienia i dezaktywacji jest niewątpliwie przypadkowa. Przez 12 pierwszych lat trudno podać regułę określająca zależność obu współczynników w stosunku do średniej długości życia. Na samym początku oraz $w$ trzech ostatnich latach jest ona 
Tabela 3. Wskaźnik zatrudnienia, dezaktywacji oraz długość życia w latach 2000-2014

\begin{tabular}{|c|c|c|c|c|c|c|c|c|c|c|c|c|c|c|c|}
\hline & 2000 & 2001 & 2002 & 2003 & 2004 & 2005 & 2006 & 2007 & 2008 & 2009 & 2010 & 2011 & 2012 & 2013 & 2014 \\
\hline $\begin{array}{l}\text { wskaźnik dezaktywa- } \\
\text { cji zawodowej }\end{array}$ & 58,00 & 56,60 & 56,90 & 58,00 & 57,70 & 59,70 & 58,20 & 59,60 & 61,40 & 61,00 & 62,50 & 62,30 & 61,90 & 61,30 & 62,20 \\
\hline $\begin{array}{l}\text { długość życia po ust. } \\
\text { wieku emerytalnym }\end{array}$ & 11,20 & 11,70 & 11,90 & 12,00 & 12,20 & 12,30 & 12,40 & 12,80 & 13,10 & 13,30 & 13,80 & 14,10 & 14,30 & 14,60 & 15,10 \\
\hline
\end{tabular}

Źródło: wskaźniki - Dane GUS, Roczne wskaźniki makroekonomicne. Cz. III 2, długość życia - http://stat.gov.pl/download/gfx/portalinformacyjny/pl/defaultaktualnosci/5470/2/8/1/lud_trwanie_zycia_2013.pdf.

Tabela 4. Długość życia i wiek emerytalny 2000-2050

\begin{tabular}{|l|c|c|c|c|c|c|c|}
\hline & $\mathbf{2 0 2 0}$ & $\mathbf{2 0 2 5}$ & $\mathbf{2 0 3 0}$ & $\mathbf{2 0 3 5}$ & $\mathbf{2 0 4 0}$ & $\mathbf{2 0 4 5}$ & $\mathbf{2 0 5 0}$ \\
\hline średnia życia ogółem & 78,35 & 79,45 & 80,65 & 81,6 & 82,55 & 83,65 & 84,3 \\
\hline śr. ustawowy wiek em. - obecny system & 64,30 & 65,00 & 65,70 & 66,3 & 67,00 & 67,00 & 67,0 \\
\hline śr. ustawowy wiek em. - poprzedni system & 62,40 & 62,40 & 62,40 & 62,4 & 62,40 & 62,40 & 62,4 \\
\hline
\end{tabular}


względnie stała. O ile więc coś można przyjać na przyszłość, to zjawisko utrzymywania sie stałej relacji zarówno współczynnika aktywności, jak i dezaktywacji zawodowej. Od czego to jednak może zależeć?

Po pierwsze wskaźnik zatrudnienia zależy od wieku dezaktywacji zawodowej. Im dłużej pracują ludzie w wieku zdolności do pracy faktycznie, tym większy pierwszy wskaźnik. Nie jest to oczywiście automatyczne, ponieważ może zachodzić efekt wypierania młodych. Jednoczesny wzrost obu wskaźników nie wskazuje jednak, by takie zjawisko miało miejsce.

Można założyć, że dla osób w dojrzałym wieku najistotniejszym motywem ubiegania się o emeryturę jest sama możliwość uzyskania tego źródła dochodu. Podstawowym czynnikiem będą tu regulacje prawne. W naszym systemie (tzw. starym) ustawowy wiek emerytalny wynosi ogółem 62,4 (średnia ważona liczebnością dla kobiet i mężczyzn). Jest to prawie dokładnie tyle, ile wiek dezaktywacji w 2014 roku. Nie jest to przypadkowe i stanowi niewątpliwie efekt zrównoważenia czynników sprzyjających odkładanie decyzji pozyskania emerytury, jak i sięgania po emeryturę wcześniejszą. W obu przypadkach w części jest to podyktowane chęcią rezygnacji $\mathrm{z}$ pracy w ogóle lub chęcią uzyskania dodatkowego dochodu. Zamierzający jednak pracować mają świadomość ryzyka utraty pracy, ponieważ uzyskanie emerytur wymaga zaprzestania stosunku pracy i ponownego zatrudnienia. Pracodawca może wykorzystać ten moment np. do zmiany warunków zatrudnienia, ma też świadomość, że w razie konieczności redukcji liczby załogi akurat ta osoba nie pozostanie bez źródła utrzymania. Z kolei decyzja wcześniejszego przejścia na emeryturę podyktowana jest wspomnianymi wcześniej czynnikami zdrowotnymi, rodzinnymi, czy brakiem szans na pracę w ogóle.

W ostatnich latach wiek dezaktywacji znacznie się podniósł. Od 2000 do 2014 roku wzrósł o 4 lata. O tyle samo wzrosła przeciętna długość życia. Nie był to proces równomierny; siła różnych czynników wpływających na decyzje potencjalnych emerytów nie była taka sama, co wpływało na liczbę tych, którzy decydowali się na wcześniejsze lub późniejsze emerytury ${ }^{3}$. $\mathrm{W}$ tym czasie nie zmieniły się $\mathrm{w}$ praktyce warunki ustawowe przejścia na emeryturę. Uwzględniając poprzednie dane, z bardzo wysokim prawdopodobieństwem można przyjąć, że wiek dezaktywacji zawodowej jest, przy względnej stałości innych czynników, zależny od długości życia. Problemem jest określenie tej zależności.

W całym okresie wiek dezaktywacji jest niższy od ustawowego wieku emerytalnego, a w ostatnich latach był on bardzo bliski tej granicy. Czy może go przekroczyć? Wykluczyć do końca tego się nie da. Jeśli jednak ten wiek określi się jako nie tyle wiek rezygnacji z pracy, ile otrzymanie emerytury, jego przekroczenie jest nieracjonalne. Obecnie równoczesne wykonywanie pracy zawodowej nie wpływa na zmniejszenie emerytury. Wręcz przeciwnie. Jej wielkość rośnie wskutek napływu nowych składek emerytalnych. Ze wzgle dów wspomnianych wcześniej pewna liczba osób będzie ociagała sie $\mathrm{z}$ podejmowaniem starań o uzyskanie emerytury, ale postawienie tezy, że wielkość tej grupy będzie rosła, nie znajduje uzasadnienia. Mogłoby tak być w sytuacji przy pogarszających się warunkach na rynku pracy (lęk przed jej utratą), ale prognozy tego nie wskazują. Gdyby obecny ustawowy wiek emerytalny (od 2013 r.) został utrzymany, rezerwy dalszego wzrostu wieku dezaktywacji zawodowej można byłoby uznać z wyczerpane. W obecnych regulacjach wiek emerytalny jednak rośnie, stąd powstaje pytanie, czy ten wskaźnik za nim nadąża.

Obecnie jest za wcześnie na odpowiedź w tej kwestii; w każdym razie dane z ostatnich lat tego nie potwierdzają. Można chyba jednak przyjać dwa założenia:

- podobnie jak w latach 2000-2015 wiek dezaktywacji zawodowej bedzie rósł;

- ustawowy wiek emerytalny nie zostanie przezeń przekroczony.

Możliwości wcześniejszego przejścia na emeryturę przesuwają się zgodnie $\mathrm{z}$ wiekiem emerytalnym, stąd można przyjąć założenie, że przez dłuższy okres będzie się utrzymywała stała różnica między wiekiem dezaktywacji zawodowej, a ustawowym wiekiem emerytalnym.

Przeciętna długość życia rosła o tyle samo lat, co różnica między nią a ustawowym wiekiem emerytalnym. To jest oczywiste. Jeśli jednak wiek emerytalny zostanie przesunięty, to warunki przejścia zmienią się zasadniczo. Tu przyjęto, że wiek dezaktywacji zawodowej przesunie się o tyle lat, o ile przesunął się ustawowy wiek emerytalny. Założeniu temu sprzyja fakt rozłoże- 
nia (w obecnym systemie) podwyżki wieku emerytalnego w dłuższym czasie. Ludzie mogą wtedy przyzwyczaić się do myśli o konieczności wydłużenia czasu pracy przed emerytura, nie intensyfikując działań służących wcześniejszemu jej otrzymaniu.

Przechodząc do prognozy na następne lata, wypada posługiwać się dwoma wariantami wieku emerytalnego, tj. obowiązującego od 2013 roku oraz wieku, który ma być przywrócony, czyli 60 lat dla kobiet, 65 dla mężczyzn. W obu wypadkach należałoby przyjąć, że wiek dezaktywacji jest w stałej proporcji do ustawowego wieku emerytalnego. Tyle że ta relacja $z$ ostatnich trzech lat w warunkach poprzedniego systemu emerytalnego wynosi 0,997 . Ponieważ posługiwanie się tak małymi wielkościami, wobec możliwego błędu prognozy, jest wielką przesada, przyjęto kolejne założenie:

- W okresie prognozy wiek dezaktywacji zawodowej w przybliżeniu będzie równy ustawowemu wiekowi emerytalnemu.

Jeśli chodzi o wiek dezaktywacji zawodowej, to jest to średnia wieku przejścia na emeryturę. Obejmuje więc zarówno tych, którzy przestali pracować w ustawowym wieku emerytalny, przed nim, jak i po nim. Współczynnik aktywności zawodowej natomiast obejmuje pracujących tylko z okresu 15-65 lat. W tej sytuacji liczba faktycznie pracujących jest większa, niż wynikałoby z przemnożenia tego współczynnika przez liczbę osób w tym przedziale wiekowym. Trzeba dodać osoby pracujące po 65 . roku życia. Co ciekawe, nie wpłynie to na liczbe osób pobierających emerytury. Można je pobierać, pracując, ale raczej niewielki odsetek ludzi zrezygnuje $\mathrm{z}$ nich w sytuacji, kiedy można otrzymywać dochody także z tego źródła. Odsetek ten więc pominięto, choć w dalszych badaniach może trzeba będzie do tego powrócić. Natomiast jeśli chciałoby się obliczać liczbe wszystkich pracujących przy użyciu tego rodzaju wskaźnika, musiałby on być skorygowany. Obliczyć należałoby go jako relację pracujących ogółem do całej ludności w wieku 15+. Określmy go jako wskaźnik zatrudnienia całkowitego.

\section{Wskaźnik zatrudnienia i udział emerytów w populacji}

O ile obliczenie tego wskaźnika np. dla roku nie nastręcza trudności, to prognozowanie jego wartości na przyszłość wymaga przyjęcia pewnych założeń. Tu przyjęto następujące:

- Zatrudnienie w danym przedziale percentylowym ludności wg wieku można przyjąc jako stabilne; długość życia wiąże się z lepszą kondycją zdrowotną w każdym przedziale, a nie np. tylko wydłużaniem okresu faktycznej niezdolności do pracy.

- Ze względu na wzrost długości życia danemu przedziałowi percentylowemu odpowiada coraz dłuższy przedział, liczony w latach.

Konsekwencje tych założeń można przedstawić przykładzie. Otóż jeżeli w 2013 roku przedział 15-65 stanowił 70\% populacji, to w roku 2020, ze względu na wzrost średniej przeżycia, to samo $70 \%$ żyjących będzie się znajdowało już w szerszym przedziale wiekowym. Można to zjawisko przedstawić jako analogię do rozciąganej gumy. Jeżeli przed rozciągniecie oznaczymy jej poszczególne części, to po rozciągnięciu każda $\mathrm{z}$ nich będzie miała taki sam udział w całości jak przez rozciągnięcie. W centymetrach będzie jednak dłuższa o tyle procent, o ile rozciągnęła się cała guma.

W tej sytuacji, jeśli średnia życia zmieni się o ok. $1 \%$, to $70 \%$ populacji nie będzie znajdowało się w wieku 15-65 lat, ale $\mathrm{w}$ wieku $15-65,6^{4}$. Podobnie będzie z przedziałem wiekowym 65 i więcej.

Jeżeli teraz, zgodnie z wcześniejszymi założeniami, przyjmiemy, że w obu grupach percentylowych zatrudnienie jest takie samo, to w roku 2020 wskaźnik zatrudnienia osób powyżej 15. roku życia będzie taki sam jak w 2013, chociaż średni wiek pracujących się zwiększy.

Niewątpliwie ten ostatni problem będzie wymagał zbadania i, najprawdopodobniej, niezbędne będą stosowne korekty. Być może wystąpią tu pewne nieliniowe zależności wskazujące, że wspomniany wskaźnik zatrudnienia ogółem (grupa 15+) będzie lekko spadał wraz wydłużaniem się średniej życia. Prawdopodobieństwo wystąpienia takiej zależności wydaje sie wzrastać wraz $\mathrm{z}$ podnoszeniem się poziomu życia w społeczeństwie ogółem. Problem ten jednak wymaga szczegółowych badań, w dalszej analizie zastosowano więc uproszczenie, polegające na przyjęcie stałości tego wskaźnika

Wskaźnik zatrudnienia ogółem w roku 2014 wyniósł dla wieku 15-64 61,7 (dane GUS, Roczne wskaźniki ekonomiczne), 
Tabela 5. Średnia życia ogółem, ustawowy wiek emerytalny (wariant obecny i mający zostać wprowadzony), populacja powyżej ustawowego wieku emerytalnego

\begin{tabular}{|l|c|c|c|c|c|c|c|c|}
\hline & $\mathbf{2 0 1 3}$ & $\mathbf{2 0 2 0}$ & $\mathbf{2 0 2 5}$ & $\mathbf{2 0 3 0}$ & $\mathbf{2 0 3 5}$ & $\mathbf{2 0 4 0}$ & $\mathbf{2 0 4 5}$ & $\mathbf{2 0 5 0}$ \\
\hline Średnia życia og. & 77,60 & 78,35 & 79,45 & 80,65 & 81,60 & 82,55 & 83,65 & 84,30 \\
\hline Ustawowy wiek em. 1 & 62,67 & 64,30 & 65,00 & 65,70 & 66,30 & 67,00 & 67,00 & 67,00 \\
\hline Ustawowy wiek em. 2 & 62,40 & 62,40 & 62,40 & 62,40 & 62,40 & 62,40 & 62,40 & 62,40 \\
\hline Cała pop. mln & 38,49 & 38,137 & 37,741 & 37,185 & 36,476 & 35,668 & 34,817 & 34,124 \\
\hline $\begin{array}{l}\text { Populacja powyżej w. emeryt } \\
\text { obecny system }\end{array}$ & $18,4 \%$ & $20,2 \%$ & $21,6 \%$ & $23,2 \%$ & $23,3 \%$ & $23,4 \%$ & $26,0 \%$ & $28,4 \%$ \\
\hline $\begin{array}{l}\text { Populacja powyżej w. emeryt } \\
\text { poprz. system }\end{array}$ & $18,6 \%$ & $23,0 \%$ & $25,0 \%$ & $26,2 \%$ & $27,9 \%$ & $30,8 \%$ & $33,5 \%$ & $36,7 \%$ \\
\hline Pop. powyżej 15 & $85,0 \%$ & $85,2 \%$ & $86,1 \%$ & $86,9 \%$ & $87,6 \%$ & $87,9 \%$ & $87,9 \%$ & $87,9 \%$ \\
\hline
\end{tabular}

Źródło: GUS, Struktura ludności według wieku od 1970, http://stat.gov.pl/obszary-tematyczne/ludnosc/ ludnosc/ludnosc-piramida/

dla osób $65+$ wynosi $4,5^{5}$. Wskaźnik dla zatrudnienia całkowitego wynosi $66,2 \%$. I tak będzie przez cały czas prognozy i o ile nie zmienią się przesłanki rezygnacji z działalności zawodowej. Przyjęto to też, że nie zmieni tego wskaźnika wydłużony wiek emerytalny. Co prawda, jeśli ma się wcześniej emeryturę, to łatwiej zrezygnować $\mathrm{z}$ pracy, tylko po co? Jeśli kondycja zdrowotna na to pozwala, lepiej pracować i dostawać emeryturę, niż tylko pozostawać przy tej ostatniej. Wysokość emerytur nie jest na tyle wysoka, by dylemat: przestać pracować lub łączyć pracę z emeryturą, był naprawdę istotny. Choć więc problem ten wymaga dalszych badań, przyjęto tu, że ustawowy wiek emerytalny nie ma istotnego wpływu na decyzję o rezygnacji $\mathrm{z}$ pracy.

Z oczywistych względów natomiast przesunięcia wieku emerytalnego, a związany z tym wiek dezaktywacji zawodowej będą miały wpływ na liczbę pobieranych emerytur. Te wielkość trzeba policzyć odrebnie.

Wiek dezaktywacji zawodowej oznacza, że, średnio rzecz biorąc, wszyscy pracujący otrzymują wówczas emeryturę. Liczba emerytów w tej sytuacji zawiera równiez pracujących powyżej wieku dezaktywacji zawodowej. Jak okazało się jednak poprzednio, ustawowy wiek emerytalny pokrywa się $\mathrm{z}$ wiekiem dezaktywacji zawodowej. W tej sytuacji liczbę emerytów zależy przede wszystkim od ustawowego wieku emerytalnego, a ściślej: liczby osób powyżej tego.
Korzystając z danych GUS, otrzymujemy wartości przedstawione w tabeli 5 .

Może zwrócić uwagę fakt, że w okresie 2030-2040 populacja emerytów w warunkach obecnych regulacji wieku emerytalnego praktycznie rośnie niemal niezauważalnie. Wynika to zarówno z faktu przesuwania się wieku otrzymania emerytury (kobiety w istniejącym systemie), jak i swoistego wcięcia w piramidzie wiekowej, będącego echem spadku urodzeń z końca lat 70. XX wieku. Skutkować to będzie także okresową stabilizacją obciążenia pracujących, niezbędnymi teoretycznie, składkami emerytalnymi (tabela 8).

Te dane w połączeniu $z$ oszacowanym powyżej wskaźnikiem zatrudnienia (stałym przez cały okres) pozwalają obliczyć obciążenia na jednego pracującego.

\section{Obciążenia pracujących}

Prognozowane parametry dotyczące zatrudnienia w okresie do 2050 roku oraz przewidywana liczba emerytów pozwalają obliczyć, ilu niepracujących przypada na jednego zatrudnionego oraz relację emerytów do pracujących. Część emerytów pracuje, a więc przynajmniej w jakimś procencie składkami pokrywają część własnej emerytury. Chodzi więc nie tyle o relację: pracujący-emeryci, ile liczba pracującychliczba emerytów. Jest to bardzo istotne dla właściwego odczytania treści tabel. Liczby w poszczególnych komórkach wynikają ze 
Tabela 6. Obciążenia na jednego pracującego przy aktualnej relacji płaca/emerytura

\begin{tabular}{|l|c|c|c|c|c|c|c|c|}
\hline & $\mathbf{2 0 1 3}$ & $\mathbf{2 0 2 0}$ & $\mathbf{2 0 2 5}$ & $\mathbf{2 0 3 0}$ & $\mathbf{2 0 3 5}$ & $\mathbf{2 0 4 0}$ & $\mathbf{2 0 4 5}$ & $\mathbf{2 0 5 0}$ \\
\hline Pracujących/niepracujących & 1,29 & 1,29 & 1,33 & 1,36 & 1,38 & 1,39 & 1,39 & 1,39 \\
\hline Prac./liczba em. obecny sys. & 3,06 & 2,79 & 2,64 & 2,48 & 2,49 & 2,49 & 2,24 & 2,05 \\
\hline Prac./liczba em. poprz. sys. & 3,03 & 2,45 & 2,28 & 2,20 & 2,08 & 1,89 & 1,74 & 1,59 \\
\hline Płace og./emerytury og. obecny sys. & 4,90 & 4,50 & 4,30 & 4,00 & 4,00 & 4,00 & 3,60 & 3,30 \\
\hline Płace og./emerytury og. poprz. sys. & 4,90 & 4,00 & 3,70 & 3,50 & 3,40 & 3,00 & 2,80 & 2,60 \\
\hline Teoretyczna skł. em. obecny system & $20 \%$ & $22 \%$ & $23 \%$ & $25 \%$ & $25 \%$ & $25 \%$ & $28 \%$ & $30 \%$ \\
\hline Teoretyczna skł. em. 2 poprz. system & $20 \%$ & $25 \%$ & $27 \%$ & $28 \%$ & $30 \%$ & $33 \%$ & $36 \%$ & $39 \%$ \\
\hline
\end{tabular}

struktury wieku społeczeństwa w poszczególnych okresach oraz przyjęcia stałego wskaźnika zastapienia i zatrudnienia ogółem.

Wiersz trzeci i czwarty tabeli 6 przedstawiają relację pracujących do liczby pobieranych emerytur, piąty i szósty - wolumenu płac do wolumenu emerytur, siódmy i ósmy odpowiadają na pytanie, ile powinna wynosić teoretyczna składka emerytalna w stosunku do płacy, aby sfinansować emerytury

Przedstawione dane nie dotyczą, jak wspomniano, społeczeństwa, ale pracujących i emerytów objętych systemem emerytalnym FUS. Może powstać wątpliwość, czy przedstawiona analiza nie jest zbyt fragmentaryczna. Emerytury rolnicze w 2014 r. wynosiły (216 tys.), i mundurowe itp. 391 tys. (GUS, http), stanowiąc ok. $12 \%$ wszystkich emerytur. Jeśli w tych dwu obszarach utrzymają się zbliżone do dotychczasowych zasady, to ich relacje do emerytur FUS nie powinny się zasadniczo zmieniać. Nawet jednak gdyby relacje pracujacy-emeryci w tych dwu sferach zmieniłyby się o dość dużo, czyli np. 10\%, to udział tych emerytur w całości wypłat emerytalnych zmieniłaby się rzędu $1 \%$.

W tej sytuacji można przyjać $\mathrm{z}$ grubsza, że choć przedstawione wskaźniki obliczone są dla gospodarki jako całości, to uwzględniając błąd prognozy $1 \%$, można je zastosować nie tylko do przewidywań tego, co się dzieje w FUS, ale przedstawiać sugestie co do obciążeń wynikających z całości systemu emerytalnego w kraju. Aby jednak zasłużyły one na miano prognozy, potrzeba tu osobnej analizy.

$\mathrm{Na}$ początku badanego okresu (2015) wymagana składka, wyliczona na pod- stawie zastosowanego modelu, wyniosła $20 \%$. Wyszło więc prawie dokładnie tyle, ile FUS otrzymuje i przeznacza na emerytury. Trzeba jednak pamiętać, że Fundusz Ubezpieczeń Społecznych finansuje też wypłaty rentowe pracowników. Jeśli się je uwzględni, to składka powinna być o ok. 7 p. proc. wyższa. Tę jednak część składki zastępuje dotacja. W 2013 r. wpływy składkowe ZUS stanowiły 71,4\%. Resztę stanowi dotacja. Jeśli jednak od tej dotacji odejmie się refundację wydatków na OFE, to jej relacja do wartości składki wyniesie dokładnie $1 / 3$, czyli właśnie wspomniane $7 \%$.

Pozostała część dotacji w 2013 roku, czyli jej $16 \%$, to refundacja za przekazane środki do OFE. Praktycznie oznacza to, że państwo finansuje nie tylko renty, ale także narastający kapitał w OFE. Pozwoli on albo zwiększyć emeryturę (wzrost wskaźnika zastąpienia), albo obniżyć składkę. Oszacowanie, na ile kapitał z OFE wpłynie na wielkość emerytury bądź składki, wymaga przyjęcia założeń co do stopy realnego zwrotu na inwestycjach portfelowych OFE. Przed kryzysem subprime założenia były bardzo optymistyczne, obecnie wypadałoby więc zastosować niższe wartości. Przyjęcie arbitralnych wielkości wydaje się jednak przynosić więcej niepewności niż je redukować. Pozostaje więc odwołać się do historycznych danych rynkowych.

Obecnie OFE nie mogą inwestować w obligacje skarbowe. Do 2013 roku mogły nabywać obligacje skarbowe. Pod koniec 2014 roku $83 \%$ ich portfela stanowiły akcje. Pomińmy tu ocenę zarówno tego rozwiązania, jak i całej idei emerytur kapitałowych, pozostawiając to innym autorom ${ }^{6}$. 
Stagnacja, a po niej trwająca ponad rok recesja na tym rynku, utrudnia prognozowania przyszłych stop zwrotu. Niepoprawne jednak metodycznie byłoby przyjmowanie arbitralnych wartości. W latach 2006-2015, a więc po akcesji do UE, który to fakt miał znaczący wpływ na polski rynek kapitałowy, średnioroczna stopa zwrotu na inwestycjach OFE wynosiła ok. 4\% ${ }^{7}$. Jest to wskaźnik wysoki, jednak przejście inwestycji z OFE wyłącznie na akcje, dłużne papiery komunalne i komercyjne, w długim okresie powinno dać wyższy zwrot w stosunku do portfela, w którym znajdują się obligacje skarbowe. Gorszy wynik na giełdzie powinien w części przynajmniej być zrekompensowany bardziej wydajną strukturą portfela.

Ta kwota nie oznacza, że o tyle przyrastało konto członka OFE. Od każdej składki Towarzystwa OFE pobierają prowizję 7\% wartości składki. Dochodzi jeszcze prowizja ZUS - 0,8\%. Kapitałem pracującym nie jest więc 2,9\% składki emerytalnej rentowej. Gdy odejmiemy te prowizje, jest to $2,7 \%$. Gdyby płace realne nie rosły, to w ciaggu 40 lub 45 lat pracy zgormadzony zostałby kapitał odpowiadający 1,08 $(40 \times 0,027)$ lub 1,12 średniej, rocznej płacy plus, w tym przypadku znaczne, odsetki.

Uwzględniając zarówno składki, jak i odsetki, można obliczyć relację zebranego kapitału do płacy realnej w dwu wariantach: pierwszy - przy założeniu, że praca realna nie rośnie (wiersz drugi). W drugim wariancie - do płacy rosnacej w tempie z lat 2005-2015, czyli 2,7\% (średnia geometryczna). W obu wierszach średnioroczna stopa inwestycji wynosi 4\%. Czwarty wiersz przedstawia narastająco wzrost płacy realnej. Piąty wiersz przedstawia relację nagromadzonego kapitału do płacy realnej w tym czasie. Przedstawiono to w jednym wariancie, a więc tylko wtedy, gdy płaca realna wzrośnie. Gdy jej wzrost jest zerowy, te relacje przedstawia wiersz drugi (tab. 7).
Płaca liczona jest następująco:

$$
\operatorname{płaca}_{0} \times(1+p)^{k}
$$

gdzie:

$p$ - przyrost płacy,

$k$ - liczba lat pracy.

Kapitał jest liczony jako suma $k$-elementowego szeregu geometrycznego

$$
\sum_{i=1}^{k} s k t \times(1+\mathrm{p})^{\mathrm{k}}(1+\mathrm{r})^{\mathrm{n}-\mathrm{k}+1}
$$

gdzie:

skt - wartość składki w roku wyjściowym,

$n$ - długość całego okresu,

$k$ - liczba lat do końca okresu,

$r$ - średnia stopa zwrotu na kapitale.

Kapitał w OFE gromadzony jest od 1999 roku. Pierwsi, którzy zaczęli wtedy odkładać mieli wówczas 50 lat. Jeśli pracowali do 65. roku życia, czyli do roku 2015, mieli kapitał w wysokości ok $71 \%$ średniej płacy z roku zerowego, tj. 1999. W tym czasie jednak płaca wzrosła o $48 \% 8$. Zeby określić, o ile środki z konta kapitałowego zwiększą emeryturę w stosunku do pozostałej jej części, trzeba podzielić kwotę nagromadzonego kapitału przez lata między wiekiem emerytalnym (w tym czasie) a długością życia. Tak samo w następnych okresach, które przedstawiono w tabeli 8. Dla osoby przechodzącej na emeryturę w 2015 roku w wieku 65 lat będzie to okres ok 12 lat.

W poprzednich wyliczeniach przedstawiano relację całości składki do płacy, pozwalającej na wypłatę emerytur przy tym samym wskaźniku zastąpienia. Tak by było, gdyby pominąć Filar OFE. Obecnie nie ma on prawie żadnego istotnego znaczenia, ponieważ składkę OFE finansuje skarb państwa, a wypłaty na emerytury stąd pochodzące są jeszcze bardzo małe.

Tabela 7. Kapitał w OFE zależnie od roku składkowego jako \% rocznej płacy

\begin{tabular}{|l|r|r|r|r|r|r|r|r|}
\hline Lata pracy & 5 & 10 & 15 & 20 & 25 & 30 & 35 & 40 \\
\hline Zebrany kap., 0 wzr. płacy (w \%) & 18 & 36 & 58 & 85 & 118 & 157 & 206 & 270 \\
\hline Zebrany kap., 2,7\% wzr. płacy rocznie (w \%) & 19 & 42 & 71 & 111 & 162 & 228 & 313 & 418 \\
\hline Płaca/płaca roku zero (w \%) & 117 & 134 & 153 & 175 & 200 & 228 & 261 & 290 \\
\hline kapital/placa2 (w \%) & 16 & 31 & 47 & 63 & 81 & 100 & 120 & 144 \\
\hline
\end{tabular}


Tabela 8. Średni okres zasilania konta kapitałowego dla poszczególnych dat

\begin{tabular}{|l|c|c|c|c|c|c|c|}
\hline & $\mathbf{2 0 2 0}$ & $\mathbf{2 0 2 5}$ & $\mathbf{2 0 3 0}$ & $\mathbf{2 0 3 5}$ & $\mathbf{2 0 4 0}$ & $\mathbf{2 0 4 5}$ & $\mathbf{2 0 5 0}$ \\
\hline Poprzedni system & 7,4 & 10,2 & 14,0 & 16,1 & 20,3 & 25,1 & 30,1 \\
\hline Obecny system & 9,3 & 12,8 & 17,3 & 20,0 & 24,9 & 29,7 & 34,7 \\
\hline
\end{tabular}

W przyszłości będą one jeszcze większe. Trzymając się więc dalej przyjętego kierunku analizy, zawartego w pytaniu, jaka powinna być składka emerytalna, by w przypadku emerytur FUS system był samowystarczalny, trzeba uwzględnić problem przypływów kapitałowych między FUS a OFE.

Należy rozpocząć od określenia średniej wartości konta kapitałowego w OFE. Tak jak dotąd, przedstawiane będzie ono nie w wartości bezwzględnej, ale jako relacja do średniej płacy. Obliczenia te są jednak dość złożone. W każdym roku pobierają emerytury różne roczniki (chodzi o rok urodzenia), co wiąże się także $\mathrm{z}$ różnymi wartościami kont kapitałowych w momencie przejścia na emeryturę. Jedni będa mieli dłuższy, inni krótszy okres płacenia składek. Najkrótszy beda mieli urodzeni w roku 1949, ponieważ był to pierwszy rocznik, który wszedł w II filar. Następni będa kolejno o jeden rok dłużej beneficjentami wpłat dla OFE. Dopiero w 2040 r. przechodzący na emeryturę będą mieli za sobą staż 40 lat płacenia składki. Mimo to, ponieważ żyć będą także wcześniejsze roczniki, średni okres płacenia tej „kapitałowej” składki będzie znacznie niższy. Stąd dla każdego roku musi być obliczona średnia ważona lat płacenia tej składki, uwzględniając liczebność poszczególnych roczników.

Przez lata wskazane w tabeli 8 będzie gromadzony kapitał na poszczególnych kontach. Srednie konto w danym roku będzie wielkością składową:

- 2,7\% od rosnącej średniej płacy,

- każdego roku odłożona wyżej wartość rośnie według stopy $4 \% 9$

- uzyskany kapitał dzielony jest przez liczbę lat życia na emeryturze.

Zabrany kapitał będzie $k$-elementową sumą postępu geometrycznego, gdzie $k-$ liczba lat pracy do momentu otrzymania emerytury. Posłużono się tu średnią ważona liczby lat pracy od początku pierwszej składki kapitałowej (nie wcześniej jednak niż 1999 roku). Wagami są udziały poszcze- gólnych roczników emerytów w populacji emerytów, którzy, pracując, odprowadzali składki kapitałowe. Tak więc w roku 2020 najdłuższy staż składkowy (20 lat) będzie miał rocznik 1955, wcześniejsze - o kolejne lata mniej. Roczniki poniżej 1948 nie mogą być brane pod uwagę (nie objął je system II filara).

W dwu ostatnich wierszach tabeli 9 przedstawiono, ile wynosi relacja części kapitałowej do średniej płacy w danym roku.

W pierwszych dwóch wierszach w tabeli 9 powtarzają dane $\mathrm{z}$ tabeli 8 . Następne dwa przedstawiają relację zgromadzonego kapitału do średniej płacy w dwu wariantach systemu emerytalnego: obecnym i poprzednim. Różnice miedzy nimi wynikają z różnych okresów gromadzenia składki, co przedstawiono w tabeli 8 .

Jeśli przyjąć, że skarb państwa dalej refunduje składke OFE, corocznie bedzie dofinansowywać system w wysokości $2,9 \%$ średniej płacy. Pod koniec pięciolecia 20202025 wpływy z OFE przewyższa tę kwotę. Bez szkody dla wskaźnika zastąpienia można będzie $\mathrm{z}$ tej dotacji zrezygnować. W następnych latach wpływy z OFE będą przewyższały odpływ składki z ZUS do tych funduszy, tj. będą większe niż $2,9 \%$.

Tak czy inaczej, wypłaty z OFE będą powiększać emerytury. Początkowo saldo: wypłaty $\mathrm{z}$ konta kapitałowego - wpływy na konto będą ujemne. Dla utrzymania tego samego wskaźnika zastąpienia różnice te powinien pokrywać skarb państwa. Później już nie bedzie to konieczne.

Jak zostało wspomniane, praca nie ma służyć wyliczeniu rzeczywistych wypłat emerytalnych, jakie wynikają z obowiązującego systemu. Jako dane wyjściowe przyjęto bowiem stałą, taką jak obecnie, relację płaca/emerytura, która w aktualnym systemie jest wielkością zmienną, wynikającą $\mathrm{z}$ istniejącego algorytmu wypłat emerytalnych. Tutaj jest inaczej, a w istocie - odwrotnie. Prezentowany scenariusz pokazuje, jak powinny zmieniać się elementy systemu 
Tabela 9. Zebrany kapitał w poszczególnych latach do płacy w danym roku (wielkości średnie) oraz jego skala powiększenia emerytury o wypłaty kapitałowe (mierzona wielkością średniej płacy)

\begin{tabular}{|l|c|c|c|c|c|c|r|}
\hline & $\mathbf{2 0 2 0}$ & $\mathbf{2 0 2 5}$ & $\mathbf{2 0 3 0}$ & $\mathbf{2 0 3 5}$ & $\mathbf{2 0 4 0}$ & $\mathbf{2 0 4 5}$ & $\mathbf{2 0 5 0}$ \\
\hline Śr. okres płacenia skł. kap. obecnie & 9,3 & 12,8 & 17,3 & 20,0 & 24,9 & 29,7 & 34,7 \\
\hline Śr. okres płacenia skł. kap. poprzednio & 7,4 & 10,2 & 14,0 & 16,1 & 20,3 & 25,1 & 30,1 \\
\hline Kapitał/płaca system em. 1 (w \%) & 28,0 & 40,0 & 53,0 & 63,3 & 81,0 & 99,9 & 119,9 \\
\hline Kapitał/płaca system em. 2 (w \%) & 23,0 & 31,0 & 43,0 & 50,0 & 63,3 & 81,0 & 99,9 \\
\hline Średnia długość życia & 78,35 & 79,45 & 80,65 & 81,6 & 82,55 & 83,65 & 84,3 \\
\hline Długość życia - ust. wiek em. obecnie & 14,1 & 14,5 & 15,0 & 15,3 & 15,6 & 16,7 & 17,3 \\
\hline Długość życia - ust. wiek em. poprz & 16,0 & 17,1 & 18,3 & 19,2 & 20,2 & 21,3 & 21,9 \\
\hline Emerytura kap/płacy real. 1 (w \%) & 2,0 & 2,8 & 3,5 & 4,1 & 5,2 & 6,0 & 6,9 \\
\hline Emerytura kap/płacy real. 2 (w \%) & 1,4 & 1,8 & 2,4 & 2,6 & 3,1 & 3,8 & 4,6 \\
\hline
\end{tabular}

regulujące wysokość składki, aby zapewnić w przyszłości ten sam wskaźnik zastapienia, z jakim teraz mamy do czynienia

Na podstawie tych założeń można obliczyć, ile powinna wynosić składka, gdyby miała w całości pokrywać bieżące wydatki emerytalne. Będzie to, jak wspomniano, odpowiadało nieco innej sytuacji niż obecnie, ponieważ obecne składki ZUS w istocie nie finansują OFE. Czyni to skarb państwa. W tabeli 10 przyjęto, że niezbędne wypłaty w całości pokrywane sa ze składki.

Punktem wyjścia tych obliczeń są dane z tabeli 6. Różnica jest rezultatem następującego działania:

$$
\begin{aligned}
& \text { wypłata z OFE jako } \\
& \text { część średniej płacy }
\end{aligned}-\begin{gathered}
2,9 \% \text { średniej } \\
\text { płacy }
\end{gathered}
$$

wynik tej operacji podwyższa/obniża składkę emerytalną, wyliczoną w tabeli 6.

Spadek niezbędnych składek wystąpi w okresie 2035-2040 w obecnym systemie, a w starym - znaczne obniżenie tempa wzrostu, jest wynikiem wspomnianego wcięcia piramidy wiekowej, co skutkuje tym, że podstawowa grupa emerytur przez pewien okres maleje (!). Oznacza to, ze nawet spadek wydajności pracy czy zatrudnienia, skutkujący zmniejszeniem wpływów składkowych nie musi ani zmniejszyć w tym okresie względnej wartości emerytury, ani wymusić większych subwencji do funduszu emerytalnego.

W sumie niezbędne przyrosty wydajności pracy, by zapewnić istniejącą relację płaca/ emerytura, są bardzo niewielkie. Wynosić powinny tyle, ile wynosi względna różnica składek. Ponieważ w tabeli 10 podane sa wielkości pięcioletnie, warto je przeliczyć na jednoroczne. W istniejącym systemie taki niezbędny wzrost jest niewielki $(0,5 \%)$, w poprzednim - około $1 \%$ rocznie. $W$ tym modelu oznaczałoby to, że przy wzroście płacy realnej brutto rocznie $2,7 \%$ należałoby przeznaczyć 0,5 względnie 1 p. proc. na sfinansowanie rosnących emerytur. Być może jednak tak szybki wzrost wydajności się skończy i zbliżymy się do tempa europejskiego. Wówczas wzrost ten, przynajmniej w sytuacji przywrócenia poprzedniego systemu, będzie na granicy możliwości utrzymania poziomu płacy realnej, względnie wskaźnika zastąpienia. Trzeba też pamiętać, że niższy wzrost płacy realnej ma też wpływ na wartość konta kapitałowego. Na jego relację do płacy prze-

Tabela 10. Składka ogółem, z uwzględnienie salda z OFE (w \%)

\begin{tabular}{|l|c|c|c|c|c|c|c|}
\hline & $\mathbf{2 0 2 0}$ & $\mathbf{2 0 2 5}$ & $\mathbf{2 0 3 0}$ & $\mathbf{2 0 3 5}$ & $\mathbf{2 0 4 0}$ & $\mathbf{2 0 4 5}$ & $\mathbf{2 0 5 0}$ \\
\hline Składka - system obecny & 23,1 & 23,6 & 24,3 & 23,7 & 22,6 & 24,6 & 26,2 \\
\hline Składka - system poprzedni & 26,8 & 28,3 & 28,8 & 30,1 & 32,6 & 34,8 & 37,4 \\
\hline
\end{tabular}


Rysunek 5. Place realne w ostatnim piętnastoleciu ${ }^{10}$

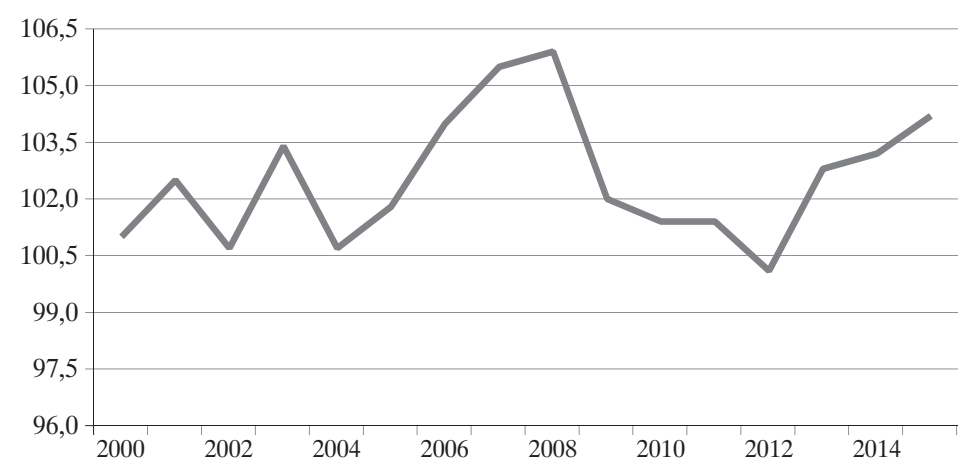

Żródło: GUS.

Tabela 12. Przyrost PKB na mieszkańca i na jedną godzinę pracy w krajach OECD

\begin{tabular}{|c|c|c|c|c|c|c|c|c|c|c|}
\hline & \multicolumn{2}{|c|}{ 1995-2014 } & \multicolumn{2}{|c|}{ 2001-2014 } & \multicolumn{2}{|c|}{$2007-2014$} & \multicolumn{2}{|c|}{ 2009-2014 } & \multicolumn{2}{|c|}{ 2007-2009 } \\
\hline & $\frac{\sqrt[N]{E}}{\stackrel{0}{E}}$ & 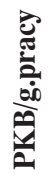 & 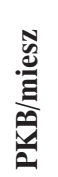 & 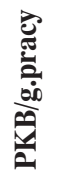 & 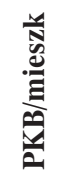 & 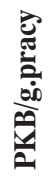 & 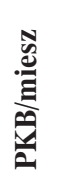 & 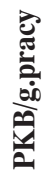 & $\frac{\sqrt[N]{E}}{\stackrel{\mathscr{E}}{E}}$ & 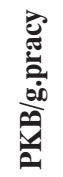 \\
\hline Polska & 4,0 & 3,8 & 3,7 & 3,1 & 2,9 & 2,8 & 2,8 & 3,2 & 3,2 & 1,8 \\
\hline Wielka Brytania & 1,5 & 1,3 & 1,0 & 1,0 & 0,0 & 0,0 & 1,2 & 0,5 & $-3,1$ & $-1,2$ \\
\hline USA & 1,4 & 1,8 & 0,9 & 1,5 & 0,2 & 1,1 & 1,3 & 0,8 & $-2,4$ & 1,8 \\
\hline EU (19) & 1,1 & 1,1 & 0,4 & 0,9 & $-0,4$ & 0,7 & 0,5 & 1,3 & $-2,5$ & $-0,6$ \\
\hline EU (128) & 1,4 & $\cdots$ & 0,8 & 1,0 & $-0,1$ & 0,7 & 0,7 & 1,3 & $-2,3$ & $-0,9$ \\
\hline G7 & 1,2 & 1,5 & 0,8 & 1,2 & 0,1 & 0,8 & 1,2 & 0,9 & $-2,6$ & 0,5 \\
\hline
\end{tabular}

Źródło: http://stats.oecd.org/Index.aspx?DataSetCode=PDB_LV.

kłada sie to w niewielkim, ale odczuwalnym stopniu w dłuższym czasie.

Sytuację w zakresie płac realnych w Polsce przedstawiają rysunek 5 i tabela 11 .

W sumie więc perspektywy dla emerytów byłyby dość optymistyczne, gdyby system opierał się wyłącznie na założeniu o utrzymaniu stałej relacji płaca/emerytura, nie zaś na bazie obecnego, skomplikowanego algorytmu. W Polsce ta relacja jest dość wysoka, ale nie wydaje się zagrażać paraliżem motywacji pracy, wynikającym ze zbyt dużych, emerytalnych narzutów płacowych. W tej sytuacji rzeczywiście wysoki wskaźnik zastąpienia jest możliwy do utrzymania, choć pod tym względem jesteśmy w czołówce UE. W Polsce jest to $63 \%$, podczas gdy w EU 27-56\% (EU 17-57\%) ${ }^{11}$. Zajmujemy, praktycznie, ex aequo z Portu- galia, Rumunia i Wegrami, czwarte miejsce. Przed tą grupą państw znajdują się Francja, Włochy i Luksemburg. Mimo to na razie nie widać potrzeby, aby był on zredukowany. Gospodarka powinna sobie poradzić, bez pogarszania sytuacji emerytów względem pracujących.

\section{Konkluzja}

Niniejszy artykuł jest projekcją obciążeń płacy składkami emerytalnymi w przyszłości. Należy ją traktować jako jeden z możliwych scenariuszy. Jego prawdopodobieństwo jest trudne do określenia, ponieważ intencja autora nie było przedstawienie tego, co będzie z najwyższym możliwym współczynnikiem ufności, ale - co by było, gdyby zamiast obecnego systemu naliczania emerytur pozo- 
stać jedynie na utrzymaniu obecnego wskaźnika zastąpienia. $\mathrm{W}$ istocie jest to swojego rodzaju test dla gospodarki, na ile wytrzyma ona kontynuację istniejących relacji płacaemerytura, w perspektywie pogłębiającego się starzenia społeczeństwa. W prognozie przyjęto też kilka innych założeń, które jednak wydają się zarówno realistyczne, jak i niezbędne. Można będzie je później wariantować, względnie precyzować, to już jednak wymaga rozszerzonych badań. Obecne więc rezultaty powinny być uznane za wstępne. Także jako wstępną należy określić tezę, że przy obecnym wieku emerytalnym zagrożenie makroekonomiczne nie wystąpią, nawet mimo utrzymania obecnego, wysokiego wskaźnika zastąpienia. Pewne problemy mogłyby się pojawić wtedy, gdyby chciano utrzymać ten wskaźnik, przywracając wiek emerytalny sprzed reformy 2013 roku.

\section{Przypisy}

1 Szerzej o tym Bera i Walczak (2012) i Góra (2008).

2 Por. Sztanderska (2008).

3 Rozkład wiekowy przechodzenia na emeryture przedstawili Góra, Guzelf, Liwiński i Siergiejuk (http).

4 Trudno przewidywać, ze minimum wieku dopuszczenia do pracy zostanie obniżone w dó1, stąd wartość przedziału urośnie w gorę.

5 Zob. przypis 2.

6 Bardzo szeroką analizę i krytyka tego rozwiązania zawiera praca Oręziak (2014).

7 Na podstawie danych KNF: Stopy zwrotu w okresie 2006-2009, 2009-2012, 2012-2015.

8 W rzeczywistości wzrosła o $49 \%$. Wartość, która wynikła $\mathrm{z}$ modelu jest wynikiem zaokraglenia tempa wzrostu do trzeciego miejsca po przecinku.

9 Ponieważ w ciągu roku składki przybywają co miesiąc, a nie np. na jego początku, to w pierwszym roku efektywna stopa rocznego wzrostu nagromadzonych w tym okresie składek wynosi nie $4 \%$, ale ok $2,2 \%$.

10 Przeciętne miesięczne wynagrodzenia realne brutto w gospodarce narodowej ogółem

11 Dane Eurostat. Aggregate replacement ratio. Code: tsdde 310.

\section{Bibliografia}

Bera, A. i Walczak, D. (2012). Problematyka wieku emerytalnego w modernizacji polskiego systemu emerytalnego. Wiadomości Ubezpieczeniowe, 1

Chłoń, A. (2013). Prognoza wpływów i wydatków Funduszu Emerytalnego do 2060. Biuletyn MRPiPS, czerwiec.

European Union pension systems adequate and sustainable? (2015). European Parliament, November

Góra, M. (2008). Dezaktywizacja zawodowa osób ubezpieczonych w ZUS w nowym systemie. W: Dezaktywizacja osób $w$ wieku okołoemerytalnym. Warszawa: Departament Analiz Ekonomicznych i Prognoz Ministerstwo Pracy i Polityki Społecznej.

Góra, M., Guzelf, T., Liwiński, J. i Siergiejuk, M., Przeglad stanu prawa majacego wptyw na dezaktywizacje osób $w$ wieku przedemerytalnym objętych systemami ubezpieczeń spotecznych oraz wplyw rozwiqzań prawnych na decyzje o przejściu na emeryturę, Załącznik 1 do raportu z badań Dezaktywizacja osób $w$ wieku okotoemerytalnym, http://psz.praca.gov.pl/documents/10828/182465 Opracowanie \%20cz\%C4\%85stkowe\%20-\%20 Za\%C5\%82\%C4\%85cznik\%201.pdf/95b7ddd932ae-43ae-a519-6c512521d1f8?t=1403859670000.

GUS, Emerytury $i$ renty 2013, http://stat.gov.pl/ obszary-tematyczne/rynek-pracy/pracujacy-zatrudnieni-wynagrodzenia-koszty-pracy/emerytury-irenty-w-2013-r-,10,4.html.

Oręziak, L. (2014). OFE, katastrofa prywatyzacji emerytur w Polsce. Warszawa: Wydawnictwo Książka i Prasa.

Pensions in Europe - Sustainability of pension systems and their interaction with economic growth (2013). Portal Bruegel Publication, December 6.

Sztanderska, U. (2008). Przyczyny wczesnej dezaktywizacji zawodowej i emerytalnej osób ubezpieczonych w ZUS. W: Dezaktywizacja osób w wieku okołoemerytalnym. Raport z badań Departament Analiz Ekonomicznych i Prognoz. Warszawa: Ministerstwo Pracy i Polityki Społecznej.

von Nordheim, F. (2014). Retirement Differences in State of Affairs and legacies across the EU28. EC/ OECD Workshop on delivering longer working lives and higher retirement ages Brussels, 12-13 November. European Commission DG EMPL D3. 